\title{
RESEARCHING OF INFLUENCE OF TUNGSTEN, SILICON AND IMPURITIES OXIDATION ON ELECTROLYTIC DISSOLUTION OF CU-ZN AND FE-NI-CO ANODES
}

\section{ИЗУЧЕНИЕ ВЛИЯНИЯ ВОЛЬФРАМА, КРЕМНИЯ И ОКИСЛЕНИЯ ПРИМЕСЕЙ НА ПРОЦЕСС ЭЛЕКТРОЛИТИЧЕСКОГО РАСТВОРЕНИЯ CU-ZN И FE-NI-CO АНОДОВ}

\author{
ALEXANDROVA T.A. ${ }^{1^{*}} ;$ GORLENKOV D. V. ${ }^{2}$; ROMANOVA N.A. ${ }^{3}$ \\ 1,2,3 Saint-Petersburg Mining University, Saint-Petersburg \\ 199106, Saint-Petersburg, Vasilievskyisland, 21 line, 2 \\ (phone: +7 96734739 90) \\ * Corresponding author \\ e-mail: alexandrova_tatyana@mail.ru
}

Received 14 March 2017; received in revised form 19 April 2017; accepted 27 April 2017

\section{RESUMO}

As condições para a reciclagem de equipamentos eletrônicos são uma tarefa urgente e altamente dependente de regulamentações e exigências ambientais. As tecnologias modernas de reciclagem de resíduos eletrônicos devem satisfazer a demanda crescente de metais e satisfazer os requisitos. A extração de metais preciosos e não-ferrosos de resíduos de microeletrônica é mais benéfica do que obtê-los de seus minérios. $O$ desenvolvimento de uma tecnologia integrada de reciclagem de resíduos de microeletrônica exige uma abordagem completa e abrangente. As composições dos concentrados e dos ânodos são apresentadas no artigo. As composições dos ânodos foram analisadas num espectrômetro de fluorescência de raios-X Lab Center XRF-1800. Foram realizadas medições dos potenciais dos ânodos de diferentes composições e em diferentes eletrólitos. Foi definido o papel das impurezas oxidantes que afetavam o progresso da dissolução eletrolítica. Conclui-se que o silício pode ser usado como uma impureza, que pode ser usada para regular e controlar o processo de dissolução eletroquímica. A adição de silício durante a fusão de ânodos permite evitar o processo de passivação da liga em eletrólito de ácido sulfúrico. Tungstênio pode ser um coletor de ouro. A oxidação do tungstênio é uma condição necessária para reduzir a perda de ouro.

Palavras-chave: Resíduos, sucata radio-eletrônica, Ouro, Tungstênio, ânodos de Cobre-Níquel.

\begin{abstract}
The conditions for the recycling of electronic equipment are an urgent task and highly dependent on environmental regulations and requirements. Modern technologies of recycling of electronic waste need to meet the increasing demand for metals and meet the requirements. Extraction of precious and non-ferrous metals from waste microelectronics is more beneficial than obtaining them from their ores. The development of an integrated waste recycling technology of microelectronics requires a thorough and comprehensive approach. Compositions of the concentrates and anodes are presented in the article. The compositions of the anodes were analyzed on X-ray fluorescence spectrometer Lab Center XRF-1800. Measurements were conducted of the potentials of the anodes of different composition and in different electrolytes. The role of the oxidant impurities that affected to progress of electrolytic dissolution was defined. It is concluded that silicon can be used as an impurity, which can be used to regulate and control the process of electrochemical dissolution. The addition of silicon during melting of anodes allows to avoid the process of passivation of the alloy in sulfuric acid electrolyte. Tungsten can be a collector for gold. The oxidation of tungsten is a necessary condition for reducing the loss of gold.
\end{abstract}


Keywords: Wastes, radio-electronic scrap, Gold, Tungsten, Copper-Nickel anodes.

\section{АННОТАЦИЯ}

Условия переработки отходов радиоэлектронной техники находятся в значительной зависимости от экологических норм и требований, что является актуальной задачей. Современные технологии переработки радиоэлектронных отходов должны обеспечивать повышенный спрос на металлы и соответствовать предъявляемым требованиям. Извлечение благородных и цветных металлов из отходов микроэлектроники является более выгодным, чем получение их из руд. Разработка комплексной технологии переработки отходов микроэлектроники требует тщательного и комплексного подхода. В статье представлены составы концентратов, поступающих на переработку. Составы полученных анодов проанализированы на рентгенофлуоресцентном спектрометре LabCenterXRF-1800. Проводились измерения потенциалов анодов различного состава и в различных электролитах. Выявлена роль окислителя примесей, влияющих на ход процесса электролитического растворения. Сделаны выводы о том, что кремний может использоваться в качестве примеси, с помощью которой можно регулировать и управлять процессом электрохимического растворения. Добавка кремния во время выплавки анодов, позволяет избежать процесса пассивации сплава в сернокислом электролите. Вольфрам может являться коллектором для золота. Окисление вольфрама - необходимое условие для снижения потерь золота.

Ключевые слова: отходы, радиоэлектронный лом, золото, вольфррам, медно-никелевые аноды.

\section{INTRODUCTION}

Requirements that the metal industry has faced in the recent years may be formulated as follows: efficiency, recycling of secondary raw materials, reduction of waste, compliance with environmental standards and regulations (Amini et al., 2007). It also should be taken into account that the global demand for metals keeps rising while the economy is becoming more ecooriented (Allwood et al., 2011).

With the phenomenal advancement and growth in the field of electronic industries, the number of consumers as well as the businesselectronic products have been raised variously and individually (per person (per capita)) in the last two decades side by side with the downward prices of the newer products (Flandineta et al., 2012; Moltó et al., 2011; Yang et al., 2013).

At the same time, the average lifetime of electronic products has also been reduced dramatically (drastically), resulting to a massive generation of End-of-life (EOL) electronic goods, popularly known as waste electrical and electronic equipment (WEEE) or Electronic waste (E-waste). The current estimate shows that nearly 45 million tons of E-waste are generated globally and annually (per annum), and the number is keep growing at an exponential rate (Ogunseitan, 2013). (Ghosh et al., 2015)

E-wastes fluctuate from large electrical appliances like refrigerators to small household electrical appliances (SHEA) like cellular phones. They are generally composed of base metals (Fe, $\mathrm{Al}, \mathrm{Cu}, \mathrm{Zn})$, rare/noble metals $(\mathrm{W}, \mathrm{Co}, \mathrm{Ni}, \mathrm{Ta}, \mathrm{Nd}$, $\mathrm{Dy}, \mathrm{Au}, \mathrm{Ag}, \mathrm{Pt}$, etc.), glass and plastics (PP, PE, $P S$, ABS), sometimes containing hazardous organic or metallic elements/compounds (Ignatiev and Surenkov, 2012; Maass and Peissker, 2011; Riedewald, 2014).

Appropriate treatments for E-wastes are needed in order to avoid environmental pollution and to recycle the precious resources. In particular, the recovery and reuse of noble or rare metals in E-wastes are increasing in importance for the industrialized countries. They are facing the difficulty to import virgin metals from developing countries, and to supply raw metals at low prices to the production industry. (Itoh, 2014)

Recycling of waste and scraps that contain precious and noble metals is an urgent task and tackling upon it we have to deal with various difficulties associated with complex nature of the products to be recycled. (Ghosh et al., 2015) 
Technologies development should be aimed at optimization of recycling of complex products that contain precious metals. (Brunner and Rechberger, 2004)

Undoubtedly, such a thorough and comprehensive approach to the technology should focus attention on both the wastes recycling chain and the methods of primary products extraction, e.g. from ores. (Sizyakov et al., 2016)

Currently there is no efficient costeffective and versatile method that satisfies the requirements of safety and ecologic norms and allows to recycle all kinds of waste. (Telyakov and Sizyakov, 2013) Therefore the task of preparing the waste for homogenization and separation of several fractions with a uniform composition and properties suitable for further metallurgical processing, is highly relevant (Tam and Tam, 2006).

\section{MATERIALS AND METHODS}

In the course of electronic scraps recycling it was found out that in order to recover precious metals to the full extent it is more appropriate to start with enriching secondary raw materials and obtain two fractions (copper-nickel concentrate and nickel-iron concentrate). (Bodénan et al., 2011)

Table 1 shows compositions of concentrates to be recycled and analyzed with the X-ray fluorescence spectrometer Lab Center XRF-1800. (Telyakov et al., 2014)

Concentrates with the compositions as above were subjected to smelting in order to produce anodes for further study of their behavior in electrolytic dissolution (Table 2).

In previous works we have indicated that impurities such as tin and lead impose certain restrictions on the anodes electrolytic recycling. Also regeneration of tin-impured electrolytes gets more complicated. Lead turns into the sludge which also makes recycling difficult. Some traces of lead in the anode composition entailits passivation in electrolytic dissolution. The electrochemical potential of the anode begins to rise which in turn results in an increased current density increased temperature of the electrolyte and a release of hydrogen on the cathode surface (Robert Perry and Don Green, 1999). The chemical and x-ray analysis of passivated anodes showed that the top of the anode experiences an increased concentration of lead in the form of $\mathrm{PbO}_{2}$. (Strizhkoand Loleyt, 2009)

Based on the above presented presumption, from which it should be noticed that the behavior of lead anodes situating in the anodes of the smelting electronic scrap, similarly to the behavior of lead anodes during regeneration of the copper electrolyte. On the surface of the lead the following processes:

$$
\begin{gathered}
\mathrm{Pb}+2 \mathrm{e}=\mathrm{Pb}^{2+} ; \\
2 \mathrm{OH}^{-}-2 \mathrm{e}^{-}=\mathrm{H}_{2} \mathrm{O}+0,5 \mathrm{O}_{2} ; \\
\mathrm{SO}_{4}{ }^{2-}-2 \mathrm{e}^{-}=\mathrm{SO}_{3}+0,5 \mathrm{O}_{2}
\end{gathered}
$$

Since the concentration of lead ions in the sulphate electrolyte is negligible and its normal potential is the most negative, the lead sulphate forms at the anode.

Sulphate is gathered on the surface of the anode and reduces its working surface, and consequently the anodic current density increases and thus it becomes possible to oxidize bivalent lead ions to tetravalent ions:

$$
\mathrm{Pb}^{2+}-2 \mathrm{e}^{-}=\mathrm{Pb}^{4+}
$$

As a result of the hydrolysis of tetravalent lead sulphate, lead peroxide is released:

$$
\mathrm{Pb}\left(\mathrm{SO}_{4}\right)+2 \mathrm{H}_{2} \mathrm{O}=\mathrm{PbO}_{2}+2 \mathrm{H}_{2} \mathrm{SO}_{4}
$$

Lead peroxide generates a protective layer on the anode which separates the metal from the electrolyte and makes it impossible to further dissolve the anode. due to that it will be passivation for the anode. The fact of passivation of copper-Nickel anode by lead peroxide was confirmed by chemical analysis and x-ray fluorescence spectrometer Lab Center XRF1800.

Smelting the iron-nickel concentrate into anodes we found that refractory tungsten turns into the slag. 


\section{RESULTS}

Our studies conducted with the microscope MM Tescan TS 5130 showed that gold uniformly distributes in the iron-nickel alloy over all phases, however its content is maximal at the high tungsten concentration point. It has been suggested that tungsten is a collector for gold (Fig. 1).

Our research of properties of these metals have shown that tungsten density is very close to that of gold $-19.3 \mathrm{~g} / \mathrm{cm} 3$, and the ionic radii are twice as large, so it is possible to collect one metal into the other. At the ambient temperature tungsten is resistant to hydrochloric, sulfuric, nitric and hydrofluoric acids of any concentration as well as to aqua regia. (Bosmans, 2012).

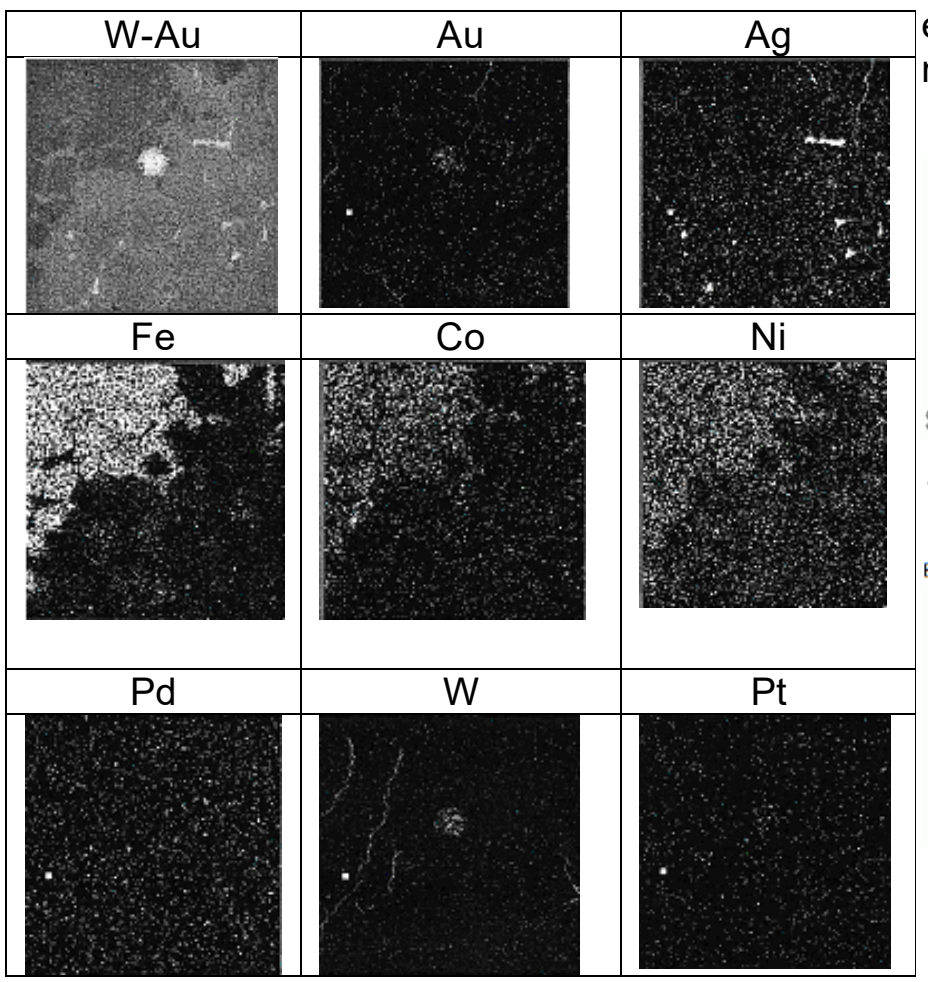

Figure 1. Results of iron-nickel concentrate smelting

When heated up to $80-100^{\circ} \mathrm{C}$ this metal is resistant to hydrofluoric acid, and very weakly reacts with hydrochloric and sulfuric acids. It reacts with nitric acid and aqua regia just a bit more traceable. In a mixture of hydrofluoric acid and nitric acid or hydrogen peroxide tungsten dissolves. (Mills et al., 2011)

This makes considerable difficulties for electrolysis sludge recycling since the nonoxidized tungsten completely turns into the sludge and its content in some electronic scraps exceeds the content of precious metals. (Strizhkoand Loleyt, 2009)

In the tungsten-iron system, compounds are formed: $\mathrm{W}_{6} \mathrm{Fe}_{2}, \mathrm{Fe}_{2} \mathrm{~W}$. The mutual solubility of the components in the solid state is negligible, and the interaction of tungsten with cobalt is exactly similar in character.

From the phase diagram of Nickel tungsten (Fig. 2) it is clear that between $(\mathrm{Ni})$ and (W) the eutectic is formed at $1500 \pm 10{ }^{\circ} \mathrm{C}$ and $20.7 \%$ (at.) W. the Curves of the liquidus and solidus (Ni) have a gentle flat maximum at 1510 ${ }^{\circ} \mathrm{C}$ and $14.7 \%$ (at.) $\mathrm{W}$, the temperature interval of crystallization (Ni) is very narrow. The solubility of $\mathrm{W}$ in $\mathrm{Ni}$ at a temperature of $1200-1250^{\circ} \mathrm{C}$ will be $17.5 \%$ (at.) that requires raising the temperature when melting the sludges of electrolysis electronic scrap and leads to loss of precious metals.

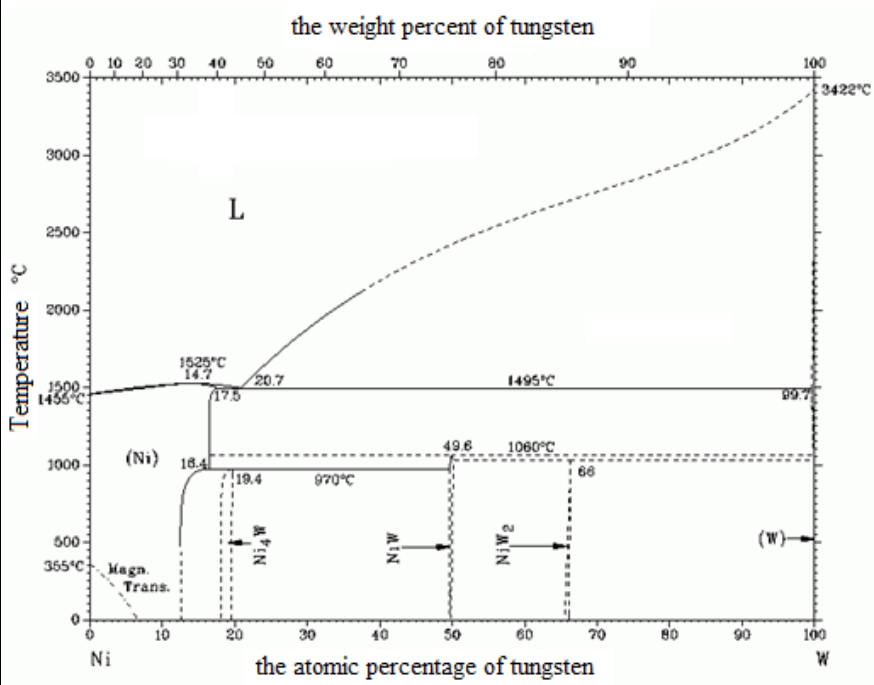

Figure 2. State diagram $\mathrm{Ni}-\mathrm{W}$

As can be seen from the above results, at a temperature of $1200^{\circ} \mathrm{C}$ in the presence of a solid oxidizer, tungsten was oxidized by $90 \%$ in 12 minutes, and at $1250^{\circ} \mathrm{C}$ in 8 minutes (Fig. 2). As a result of contact of the oxidized layer of tungsten with oxygen, produces a high tungsten oxide $\mathrm{WO}_{3}$.

In the temperature range of 1000 $1300^{\circ}$ Coxidation mechanism depends to a large extent on temperature and pressure. At a temperature of $1000^{\circ} \mathrm{C}$ and oxygen pressure of $0.1 \mathrm{~atm}$. the oxide layer is formed, and at $1200^{\circ} \mathrm{C}$ and above and an oxygen pressure of $0.01 \mathrm{~atm}$. the sample is not obtained oxide film, which can 
be measured. When a certain temperature value within this interval, the theoretical rate of evaporation becomes greater than the rate of oxidation. The value of this temperature depends on the oxygen pressure.

In practice, the sintering of tungsten concentrates with soda is carried out at 800$850^{\circ} \mathrm{C}$ in tubular rotary furnaces. penetration degree is $98-99 \%$, at consumption of soda is $160 \%$ of the theoretically required amount for the reaction.

As a result of smelting Nickel-iron concentrate obtained in the slag after oxidation, containing of $35.7 \% \mathrm{Fe}$ and $0.4 \% \mathrm{~W}$, is subjected to a process of sintering with soda at a temperature of $850^{\circ} \mathrm{C}$. Obtained sinters are treated with water at $80-90^{\circ} \mathrm{C}$, the result is a solutions of sodium tungstate (100-120 g/l WO $\mathrm{W}_{3}$ ), and dump cakes

It can be possible to avoid collection of gold on tungsten if we manage to get rid of tungsten through its oxidation and turning into the slag. Then precious metals collected in tungsten will remain in the iron-nickel alloy (Zimring, 2005).

We smelted the iron-nickel concentrate in the "Tamman" furnace at $1250^{\circ} \mathrm{C}$ (Baimakov and Jurin, 1962) and received three anodes from the magnetic fraction.

The first anode was smelted out of the magnetic fraction in a graphite crucible without any additives for the second anode we only added nitrate $\left(\mathrm{KNO}_{3}\right)$ during smelting and while smelting the third anode we added quartz sand $\left(\mathrm{SiO}_{2}\right)$ and nitrate $\left(\mathrm{KNO}_{3}\right)$.

Further on we studied those anodes with the scanning electron microscope TESCAN VEGA Sem 3 and received the following results about the composition of the anodes subjected to electrolytic dissolution in the laboratory facility (Table 2).

During oxidation of the iron-nickel concentrate we analyzed the degree of tungsten oxidation against the process temperature. In the oxidizing atmosphere tungsten oxidizes almost completely (Loleyt et al., 2009). Initially, its content in the alloy is $0.4 \%$ of the total composition, after the oxidation its content reduced to $0.03 \%$, so respectively, all tungsten turned into the slag $(\sim 0.4 \%)$.

At the temperature of $1200^{\circ} \mathrm{C}$ with a solid oxidant tungsten oxidized by $50 \%$ in 4 minutes; $65 \%$ in 6 min and $90 \%$ in 12 minutes; while at the temperature of $1250^{\circ} \mathrm{C}$ - by $66 \%$ in 4 minutes, $82 \%$ in 6 minutes, $90 \%$ in 8 minutes (Fig. 3).

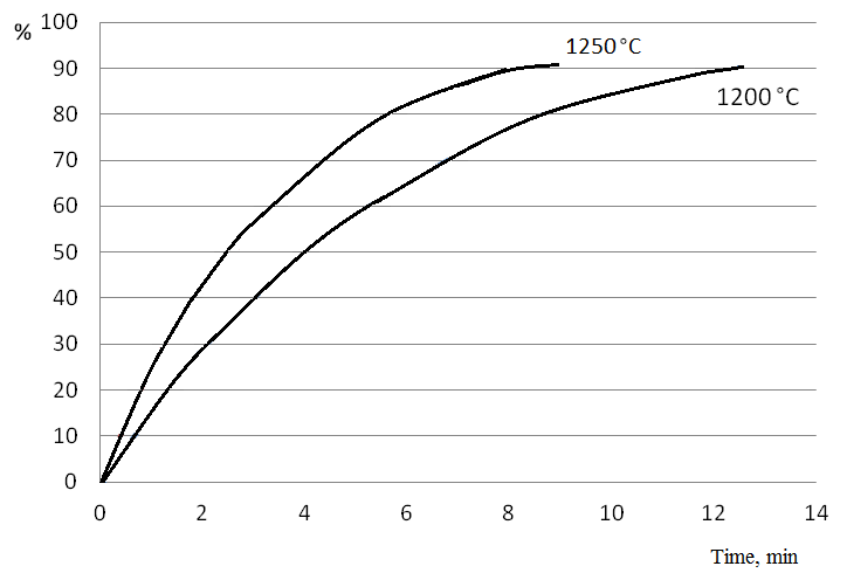

Figure 3. The rate of tungsten oxidation at temperatures of 1200 to $1250^{\circ} \mathrm{C}$

Our research in kinetics of tungsten oxidation made it possible to determine the apparent activation energy $(148.3 \mathrm{~kJ} / \mathrm{mol})$ for the oxidation the iron-nickel concentrate with tungsten by a solid oxidant and the figure proved quite high. Therefore the tungsten oxidation reaction apparently proceeds in the kinetic area thus temperature is the main factor of removing tungsten from the iron-nickel smelt (Gorlenkov et al., 2011).

The research to determine the potential behavior during the electrolytic dissolution of anodes received from the iron-nickel concentrate (Fig. 4) showed that when using $20 \% \mathrm{KNO}_{3}$ as an oxidizing agent there is practically no tungsten and the content of $\mathrm{Pb}$ and $\mathrm{Sn}$ in the anode reduces from $7 \%$ and $4.1 \%$ to $0.2 \%$ and $0.3 \%$, respectively. (Gorlenko et al., 2015).

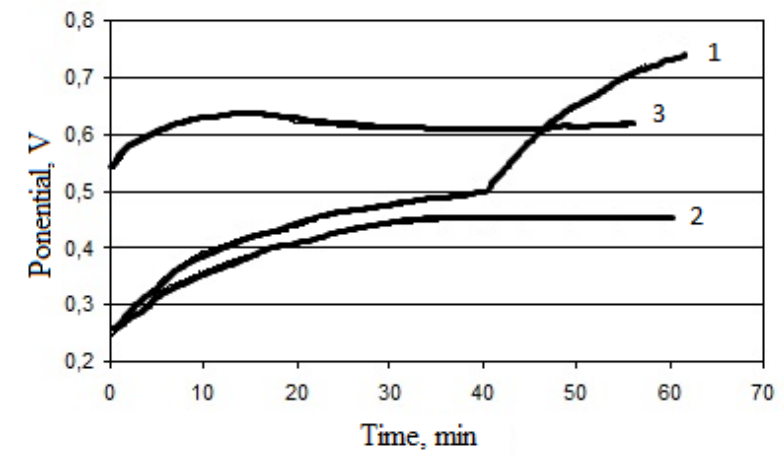

Figure 4. Results of potentials measurements in the electrolysis process:

1 - anode without additives; 2 - anode with an oxidant; 3 - anode with an oxidant and silicon 
When the anode is electrolytically dissolved in a one-molar nickel sulfate solution (analytical grade reagent GOST 4465-74) with no oxidant, the anode potential gradually increased to $0.5 \mathrm{~V}$ and in 10 minutes its value reached 0.65 $\mathrm{V}$ with a further increase to $0.7-0.72 \mathrm{~V}$. When we electolysed the anode made from smelted concentrates with $\mathrm{KNO}_{3}$ as an additive making $20 \%$ of the concentrate weight, the anode potential was lower but it also gradually increased up to $0.45 \mathrm{~V}$ and remained at this level till the end of the experiment. When smelting the third anode we used $20 \% \mathrm{KNO}_{3}$ as an additive together with quartz sand $\left(\mathrm{SiO}_{2}\right)$. The initial anode potential rose to $0.55 \mathrm{~V}$ and within the first 15 minutes the value increased up to $0.65 \mathrm{~V}$, then it leveled off at $0.62 \mathrm{~V}$ and did not change till the end of the experiment.

Also, we have made experiments to study the behavior of the potentials of the obtained anodes when their electrolytic dissolution in different electrolytes.

The anodes were subjected to electrochemical dissolution in a one-molar solution of $\mathrm{NiSO}_{4} \cdot 7 \mathrm{H}_{2} \mathrm{O}$ by adding $30 \mathrm{~g} / \mathrm{H} \mathrm{H}_{2} \mathrm{SO}_{4}$ (conc.) at a temperature of $25^{\circ} \mathrm{C}$ and a cathodic current density $230,0 \mathrm{~A} / \mathrm{m}^{2}$. An iron cathode was used and the voltage on the bath was $6 \mathrm{~V}$.

As a second electrolyte, a one-molar solution of $\mathrm{CuSO}_{4} \cdot 5 \mathrm{H}_{2} \mathrm{O}$ with addition of $30 \mathrm{~g} / \mathrm{I}$ of $\mathrm{H}_{2} \mathrm{SO}_{4}$ (conc.) Was used. The electrolyte temperature is $250^{\circ} \mathrm{C}$, the cathode is copper and the cathodic current density is $230.0 \mathrm{~A} / \mathrm{m}^{2}$. The voltage on the bath is $6 \mathrm{~V}$.

To compare the characteristics of the behavior of the potentials of the studied anodes and explore the possibility of using different electrolytes in the process of electrolytic dissolution, tests were carried out in which copper-Nickel and iron-Nickel-cobalt anodes were dissolved and alternately in the Nickel and copper electrolytes.

The carried out tests allowed us to obtain data about the behavior of the dependence of potential on time, are given in figures 5 and 6 .

Figure 3 shows plots of the dissolution potential of a copper-zinc anode versus time in different electrolytes. For the first graph (curve 2), an increase in the dissolution potential of an anode containing silicon is characteristic.

At the same time, for the second anode (curve 2') not containing silicon, a decrease in the potential was observed and the jump of potential dissolution after 60 minutes of the process due to the buildup of the oxide film on the surface of the anode, which is typical and predictable phenomenon for the electrochemical dissolution process of the alloy of this composition (Table 2) in a solution of $\mathrm{CuSO}_{4} \cdot 5 \mathrm{H}_{2} \mathrm{O}$.

The strongest influence of the oxide layer in the potential value of copper-zinc anode was observed by dissolving it in the Nickel electrolyte. The potential of the anode (curve 1) increased dramatically, almost doubled in the 20 minute process (from 450 to $850 \mathrm{mV}$ ). After that the oxide film has collapsed, the value of the potential decreased slightly (to $750 \mathrm{mV}$ ) and for the rest of time gradually increased and approached to $800 \mathrm{mV}$.

The use of a solution of $\mathrm{NiSO}_{4} 7 \mathrm{H}_{2} \mathrm{O}$ as an electrolyte to dissolve the copper-zinc anode with silicon gives rather low potential values (about $400 \mathrm{mV}$ ) and a curve curve without characteristic peaks and troughs (curve 1 ').

The presence of silicon in the anode alloy and under given conditions provides both a reduction in the dissolution potential and a smooth characteristic of the dependence of the potential on time.

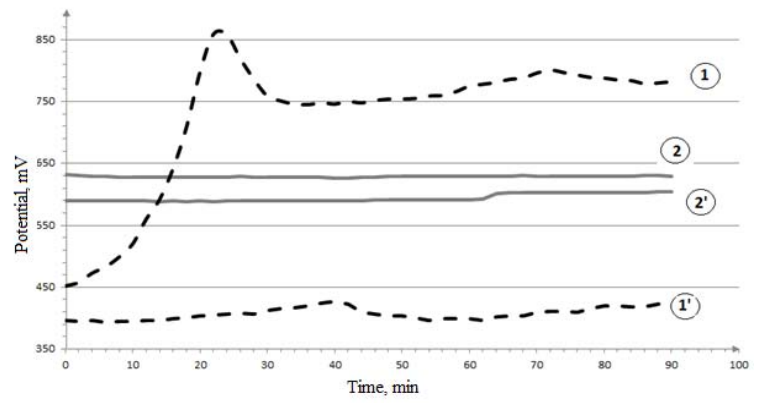

Figure 5. Copper-zinc anode in Nickel $\left(\mathrm{NiSO}_{4} \cdot 7 \mathrm{H}_{2} \mathrm{O}\right)$ and copper $\left(\mathrm{CuSO}_{4} \cdot 5 \mathrm{H}_{2} \mathrm{O}\right)$ electrolytes

1 - anode without silicon in a solution of $\mathrm{NiSO}_{4} \cdot 7 \mathrm{H}_{2} \mathrm{O}$; 1 ' - anode with silicon in a solution of $\mathrm{NiSO}_{4} \cdot 7 \mathrm{H}_{2} \mathrm{O}$; 2 anode with silicon in a solution of $\mathrm{CuSO}_{4} \cdot 5 \mathrm{H}_{2} \mathrm{O} ; 2$ anode without silicon in a solution of $\mathrm{CuSO}_{4} \cdot 5 \mathrm{H}_{2} \mathrm{O}$.

When dissolving the anodes obtained from the magnetic fraction, a similar pattern was observed. The dissolution of the iron-nickel-cobalt anode without silicon in $\mathrm{CuSO}_{4} 5 \mathrm{H}_{2} \mathrm{O}$ solution, in the first 20 minutes of the process, the potential 
doubled from 900 to $1800 \mathrm{mV}$ (curve 1) and for the rest of the time, the potential value did not fall below $1800 \mathrm{mV}$.

The increase in electrolyte temperature from 25 to $75-80^{\circ} \mathrm{C}$ was observed in parallel with the decomposition of the electrolyte characterized by liberation of hydrogen at the cathode.

Dissolving a similar anode, but with silicon (curve 1 '), under the same conditions, significantly reduces the potential (up to $800 \mathrm{mV}$ ) and flatten the potential-time curve.

Using a solution of $\mathrm{NiSO}_{4} \cdot 7 \mathrm{H}_{2} \mathrm{O}$ as an electrolyte to dissolve the anodes obtained by dissolving the magnetic fraction of radio electronic scrap seems to be preferable. The dissolution of the silicon-free anode (curve 2) occurred with increasing potential only for the first 40 minutes, and then the process continued at values not exceeding $670 \mathrm{mV}$. Dissolution proceeded evenly without significant changes in the temperature of the electrolyte.

The addition of silicon to the anode alloy further reduces the potential value to $600 \mathrm{mV}$ and conducts the process evenly without sudden changes in the potential values, as shown in curve 2 'in Fig. 6.

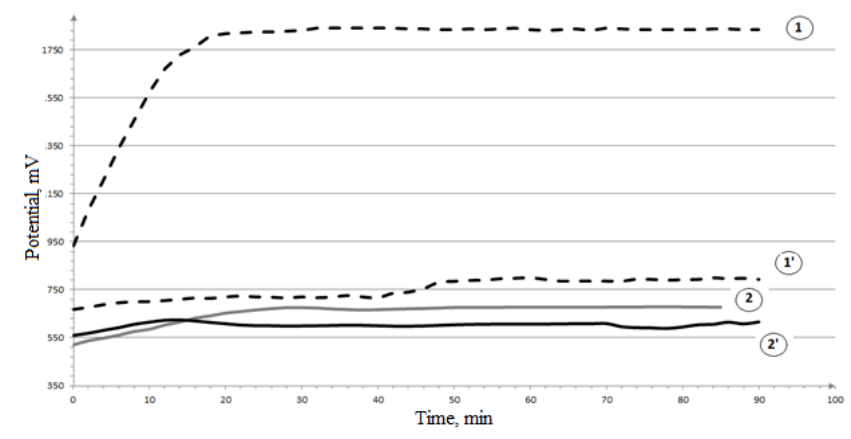

Figure 6. Iron-Nickel-cobalt anode in Nickel $\left(\mathrm{NiSO}_{4} \cdot 7 \mathrm{H}_{2} \mathrm{O}\right)$ and copper $\left(\mathrm{CuSO}{ }_{4} \cdot 5 \mathrm{H}_{2} \mathrm{O}\right)$ electrolytes

1 - anode without silicon in a solution of $\mathrm{CuSO}_{4} \cdot 5 \mathrm{H}_{2} \mathrm{O}$; 1 ' - anode with silicon in a solution of $\mathrm{CuSO}_{4} \cdot 5 \mathrm{H}_{2} \mathrm{O} ; 2$ anode without silicon in a solution of $\mathrm{NiSO}_{4} \cdot 7 \mathrm{H}_{2} \mathrm{O} ; 2^{\prime}$ ' anode with silicon in a solution of $\mathrm{NiSO}_{4} \cdot 7 \mathrm{H}_{2} \mathrm{O}$

\section{CONCLUSIONS}

On the basis of the obtained data, it can be concluded that silicon can be used as an impurity with which it is possible to regulate and control the process of electrochemical dissolution.

In all cases, the silicon flattens the potentiometric curve and, except for curve 1 in figure 5 , reduces the potential dissolution of the anode, which leads to lower power consumption, or allows to increase the current density to accelerate the process of electrolytic dissolution, if necessary. Moreover, the addition of silicon has allowed to avoid the process of passivation of the alloy in sulphuric acid electrolyte.

Maximum gold content at the high tungsten concentration point allows to assume that tungsten may be a collector for gold. Unoxidized tungsten is fully transferred to the sludge and collects gold, which leads to significant losses. Oxidation of tungsten is a necessary condition for reducing gold losses.

Using $20 \% \quad \mathrm{KNO}_{3}$ as a solid oxidizer allows to oxidize tungsten as well as such metal impurities as tin and lead that adversely affect the electrochemical dissolution of anodes.

Silicon can be used as an additive in anode smelting which allows to regulate and control electrochemical dissolution. Silicon levels off the potentio-metric curve which leads to lower energy consumption or allows to increase the current density in order to accelerate electrolytic dissolution in case of necessity. Moreover silicon additive helps to avoids alloy passivation in the sulfuric acid electrolyte.

\section{REFERENCES}

1. Allwood, J. M., Ashby, M. F., Gutowski, T. G., Worrell, E. Material efficiency, Resources, Conservation and Recycling, 2011, 55, 362 381.

2. Amini, S. H. Remmerswaal, J. Castro, M.B. and Reuter, M.A. Quantifying the quality loss and resource efficiency of Recycling by means of exergy analysis. Journal of Cleaner Production, 2007, 15, 907-918.

3. Baimakov, J. V., Jurin, A. I. Electrolysis in Hydrometallurgy. Metallurgizdat, Moscow, 1962.

4. Bodénan, F., Hanrot, F., Moulin, I., Poirier, J. "Recycling physically sorted steelworks slag for the metallurgical and cement industries: conclusions of the ORLA research project". Proceedings of the 12th 
European Congress and exhibition on Advanced Materials and Processes (Euromat 2011).Session C52, 12 - 15 sept 2011, Montpellier, France, 2011.

5. Bosmans, A. Enhanced Landfill Mining: a crucial role for Waste-to-Energy technologies. Journal of Cleaner Production, 2012.

6. Brunner, P. H., Rechberger, H. Practical Handbook of Material Flow Analysis, Lewis Publishers, Boca Raton, FL, ISBN 1566706041, 2004, 336.

7. Flandineta L., TedjaraF.,Ghettac V., Fouletiera J. Metals recovering from waste printed circuit boards (WPCBs) using 123 molten salts, J. Hazard. Mater.2012, 213214, 485-490.

8. Ghosh, B., Ghosh, M. K., Parhi, P., Mukherjee, P. S., Mishra B.K. Waste Printed Circuit Boards Recycling: An Extensive Assessment of Current Status, Journal of Cleaner Production, accepted manuscript, 2015.

9. Gorlenko, D. V., Telyakov, A. N., Alexandrov, T. A., Zakirov, A. I., Schmidt, D. V. Method of Extracting Precious Metals from Electronic Industry Wastes, patent number 2553320, IPC C25C1, 20, as of 18.05.2015, 2015.

10. Gorlenkov, D. V., Telyakov, A. N., Rubis, S. A. Developing an Effective Technology forRecyclingof Industrial Raw Materials Containing Precious Metals, St. Petersburg, 2011.

11. HillCompanies, 1999.

12. Ignatiev V., Surenkov A. Comprehensive nuclear materials, Material Performance in Molten Salts, Elsevier, 2012, 5, 124 221250 Chapter 5.

13. Itoh $\mathrm{H}$. The recent trend of e-waste recycling and rare metal recovery in Japan. Nagoya University, EcoTopia Science Institute, Japan WIT Transactions on Ecology and The Environment, 2014, 180.

14. Loleyt, S. I., Strizhko, L.S., Fokin, O. A. Peressadi S.S. Research and Development of Electronic Scraps Firing Technology, Non-Ferrous Metals, 2009, 1, 44-47.

15. Maass P., Peissker P. Handbook of Hot-dip Galvanization, Wiley-VCH, Weinheim, 2011.

16. Mills, S. J., Kartashov, P. M., Kampf, A. R., Rumsey. Tungsten, CNMNC Newsletter No. 9, 2539, Mineralogical Magazine, 2011, 75.
17. Moltó J., Egea S., Conesa J. A., Font R. Thermal decomposition of electronic wastes: mobile phone case and other parts, 130 Waste Manage. 2011, 31, 2546-2552.

18. Riedewald F. Process for the Recycling of Waste Batteries and Waste Printed Circuit Boards in Molten Salts or Molten 135 Metals, WO 2014/167139 A2, 2014.

19. Robert Perry H., Don Green W. Perry's chemical engineers' handbook, The McGraw-Sizyakov, V. M., Vlasov, A. A., Bazhin, V. Y. Strategic Objectives of Russia Metallurgical Industry, Non-Ferrous Metals, 2016, 1, 52-58.

20. Strizhko, L. S., Loleyt, S. I. Extraction of Non-Ferrous and Precious Metals from Electronic Scraps. M.: "Ore and Metals", 2009.

21. Tam, V. W. Y., Tam, C. M. A review on the viable technology for construction waste recycling. Resource Conservation Recycling, 2006, 47, $209-211$

22. Telyakov, A. N., Alexandrova, T. A., Neezhko, M. A. Features of Electronic Scrap Concentrates Smelting, Metallurg, 2014, 9, 45-47

23. Telyakov, A. N., Sizyakov, V. M. Theory and Practice of Extraction of Precious Metals in a Complex Electronic Scrap Recycling with Copper Melt Oxidizing Smelting, The National Mineral Resources University "Mining", St. Petersburg, 2013.

24. Yang X., Sun L., Xiang J., Hu S., Su S. Pyrolysis and dehalogenation of plastics from waste electrical and electronic equipment 134 (WEEE): a review, Waste Manage. 2013, 33 (2), 462-473.

25. Zimring C. A. Cash for Your Trash: Scrap Recycling in America. New Brunswick, NJ: Rutgers University Press, 2005. 
Table 1.Compositions of nationally-made concentrates recovered from electronic scraps

\begin{tabular}{|c|c|c|c|}
\hline \multicolumn{4}{|c|}{ Composition of iron-nickel concentrates, $\%$} \\
\hline $\mathrm{Ni}$ & $\mathrm{Cu}$ & Co & $\mathrm{Zn}$ \\
\hline 43,4 & 1,4 & 12,2 & 0,07 \\
\hline 36,8 & Сл. & 10,01 & 0,01 \\
\hline$P d$ & $\mathrm{Pt}$ & $\mathrm{Pb}$ & Sn \\
\hline 0,03 & 0,01 & 3,7 & 4,1 \\
\hline 0,01 & Сл. & 4,1 & 4,8 \\
\hline \multicolumn{4}{|c|}{ Composition of copper concentrates, $\%$} \\
\hline $\mathrm{Ni}$ & $\mathrm{Cu}$ & Co & $\mathrm{Zn}$ \\
\hline 4,76 & 75,3 & 0,03 & 7,1 \\
\hline 3,2 & 83,9 & Сл. & 3,0 \\
\hline$P d$ & $\mathrm{Pt}$ & $\mathrm{Pb}$ & Sn \\
\hline 0,5 & 0,01 & 1,4 & 2,4 \\
\hline 0,4 & 0,01 & 1,5 & 2,6 \\
\hline
\end{tabular}

Composition of iron-nickel concentrates, $\%$

\begin{tabular}{|c|c|c|}
\hline $\mathrm{Fe}$ & $\mathrm{Ag}$ & $\mathrm{Au}$ \\
\hline 30,4 & 0,21 & 0,83 \\
\hline 38,4 & 0,28 & 0,57 \\
\hline W & $\Pi p$ & In total \\
\hline 0,4 & 3,25 & 100 \\
\hline 0,5 & 4,52 & 100 \\
\hline \multicolumn{3}{|c|}{ Composition of copper concentrates, $\%$} \\
\hline $\mathrm{Fe}$ & $\mathrm{Ag}$ & $\mathrm{Au}$ \\
\hline 0,07 & 3,3 & 0,3 \\
\hline 0,05 & 2,7 & 0,2 \\
\hline W & $\Pi p$ & In total \\
\hline- & 4,83 & 100 \\
\hline- & 2,44 & 100 \\
\hline
\end{tabular}

Table 2.Compositions of Ni-Co-Fe and $\mathrm{Cu}-\mathrm{Zn}$ anodes

\begin{tabular}{|c|c|c|c|}
\hline \multicolumn{4}{|c|}{ Compositions of $\mathrm{Ni}-\mathrm{Co}-\mathrm{Fe}$ anodes, $\%$} \\
\hline № & $\mathrm{Ni}$ & $\mathrm{Cu}$ & Co \\
\hline 1 & 44,8 & 5,30 & 10,0 \\
\hline 2 & 47,4 & 9,40 & 9,30 \\
\hline \multirow[t]{2}{*}{3} & 42,3 & 7,20 & 3,4 \\
\hline & $\mathrm{Pd}$ & $\mathrm{Pt}$ & $\mathrm{Si}$ \\
\hline 1 & 0,02 & Сл. & - \\
\hline 2 & 0,03 & - & - \\
\hline 3 & 0,02 & - & 5,40 \\
\hline \multicolumn{4}{|c|}{ Compositions of $\mathrm{Cu}-\mathrm{Zn}$ anodes, $\%$} \\
\hline № & $\mathrm{Ni}$ & $\mathrm{Cu}$ & Co \\
\hline 1 & 3,03 & 80,1 & 0,08 \\
\hline \multirow[t]{2}{*}{2} & 3,71 & 68,7 & 0,03 \\
\hline & $\mathrm{Pd}$ & $\mathrm{Pt}$ & $\mathrm{Si}$ \\
\hline 1 & 0,56 & 0,01 & - \\
\hline 2 & 0,48 & - & 6,20 \\
\hline
\end{tabular}

\begin{tabular}{|c|c|c|c|c|}
\hline \multicolumn{5}{|c|}{ Compositions of Ni-Co-Fe anodes, \% } \\
\hline № & $\mathrm{Zn}$ & $\mathrm{Fe}$ & $\mathrm{Ag}$ & $\mathrm{Au}$ \\
\hline 1 & 0,07 & 25,6 & 3,10 & 0,60 \\
\hline 2 & 0,06 & 30,7 & 0,23 & 0,32 \\
\hline \multirow[t]{2}{*}{3} & 0,08 & 35,4 & 4,2 & 0,6 \\
\hline & $\mathrm{Pb}$ & Sn & W & other \\
\hline 1 & 3,70 & 4,10 & 0,40 & 2,04 \\
\hline 2 & 0,20 & 0,30 & 0,02 & 1,96 \\
\hline 3 & 0,20 & 0,35 & 0,03 & 0,65 \\
\hline \multicolumn{5}{|c|}{ Compositions of Cu-Zn anodes, \% } \\
\hline № & $\mathrm{Zn}$ & $\mathrm{Fe}$ & $\mathrm{Ag}$ & $\mathrm{Au}$ \\
\hline 1 & 7,00 & 0,05 & 3,11 & 0,01 \\
\hline \multirow[t]{2}{*}{2} & 12,9 & 0,75 & 0,31 & 1,32 \\
\hline & $\mathrm{Pb}$ & Sn & W & other \\
\hline 1 & 2,20 & 1,25 & 0,50 & 2,04 \\
\hline 2 & 1,75 & 1,30 & 0,80 & 1,55 \\
\hline
\end{tabular}

PERIÓDICO TCHÊ QUÍMICA•www.periodico.tchequimica.com• Vol. 14 N. 28.

• ISSN 1806-0374 (impresso) • ISSN 1806-9827 (CD-ROM) • ISSN 2179-0302 (meio eletrônico)

(C) 2010. Porto Alegre, RS. Brasil

The Periódico Tchê Química (ISSN: 1806-0374; 2179-0302) is an open-access journal since 2004. Journal DOI: 10.52571/PTQ. http://www.tchequimica.com. 